\title{
Do migrant remittances promote human capital formation? Evidence from 89 developing countries
}

\begin{abstract}
The few published empirical studies on the effect of migrant remittances on educational attainments are roughly based on cross-sectional microdata from household surveys. This paper applies the generalised method of moments (GMM) estimator on aggregate level data from 1970 to 2010 in five-year intervals to examine the impact of migrant remittances on human capital formation in 89 developing countries. The estimation results show that, on average, an increase in migrant remittance inflows by $1 \%$ is associated with a $2 \%$ rise in years of schooling at both the secondary and tertiary levels. This suggests that migrant remittances have the potential to relax liquidity constraints and generate spillover effects that facilitate more schooling opportunities in remittance-receiving countries.
\end{abstract}

Keyword: Remittances; Human capital formation; Aggregate level data; Dynamic model; Developing countries 